\title{
BIOLOGY
}

\section{Growth and reproductive biology of the amphidromous shrimp Palaemon pandaliformis (Decapoda: Caridea) in a Neotropical river from northeastern Brazil}

\author{
Lucas R.P. Paschoal ${ }^{1,2^{*}}$, Fernanda J. Guimarães ${ }^{2} \&$ Erminda C.G. Couto ${ }^{2}$
}

\begin{abstract}
${ }^{1}$ Invertebrate Morphology Laboratory, Departamento de Biologia Aplicada, Universidade Estadual Paulista Júlio de Mesquita Filho. Via de Acesso Professor Paulo Donato Castellane, 14884-900 Jaboticabal, SP, Brazil.

${ }^{2}$ Laboratório de Ecologia Bêntica, Departamento de Ciências Biológicas, Universidade Estadual de Santa Cruz. Campus Soane Nazaré de Andrade, Rodovia Ilhéus-Itabuna, km 16, 45662-900 Ilhéus, BA, Brazil. *Corresponding author. E-mail: lucasrezende20@gmail.com
\end{abstract}

\begin{abstract}
Population biology, growth and reproductive aspects of the amphidromous shrimp Palaemon pandaliformis (Stimpson, 1871) were investigated in a Neotropical river of northeastern Brazil. The specimens were collected every month from September 2009 to August 2010. Total and monthly sex ratios deviated in favour of males. Von Bertalanffy growth parameters indicated that the females grew more rapidly, reached larger sizes, and had a longer life span than males. We also observed continuous reproductive activity and juvenile recruitment throughout the year. Relations between the number of eggs (fecundity) and body size indicated that fecundity in females increase with size. Compared with previous results, some population biology parameters of the freshwater population of $P$. pandaliformis differ from estuarine populations. The reproductive aspects analyzed here and their comparison with other marine species were consistent with the hypothesis that Palaemonidae species are undergoing an adaptation process and colonizing fresh water environments.
\end{abstract}

KEY WORDS. Morphometric relationships; Palaemonidae; population biology; reproduction; sexual dimorphism.

Caridean shrimps are found in all aquatic environments and biogeographic regions on the planet. Most representatives of this Infraorder are restricted to marine or freshwater environments, with the exception of amphidromous shrimps (BAUER 2004, 2013, De Grave et al. 2008, De Grave \& Fransen 2011). Amphidromous adult shrimps live, grow, reproduce, and spawn in freshwater environments, but their planktonic larvae develop in estuarine or marine environments. Generally, larval transport to saline environments by river drift occurs during the rainy season, when reproductive activity is at its peak. Later in their initial development, the larvae migrate back upstream during the dry season to the adult environment until they become adults themselves. This strategy occurs in some families, namely Atyidae, Palaemonidae and Xiphocarididae. Nevertheless, only Palaemonidae, more precisely the genus Palaemon Weber, 1795 , harbour strictly marine and freshwater species as well as amphidromous species (Bauer 2004, 2013, Bauer \& Delahoussaye 2008, De Grave \& Ashelby 2013).

Known as "potitinga" in Brazil, Palaemon pandaliformis (Stimpson, 1871) is a small amphidromous species with a high tolerance to salinity variations. This shrimp has a wide geographical distribution along the Western Atlantic, from Cuba to southern Brazil (Melo 2003, Foster et al. 2009, FerReira et al. 2010). It lives on sand or mud substrates under stones or plant debris, and is associated with several macrophytes species and marginal vegetation of rivers with direct or indirect ocean connections (Coelho 1964, Almeida et al. 2006, Paschoal et al. 2013a). Palaemon pandaliformis is directly involved in organic nutrient cycling and it is an important component of the diet of many birds and fresh/saltwater fish species (TeIXeIra 1997, BOND-BUCKUP \& BUCKUP 1999).

Recently, AsHelby et al. (2012) proposed the creation of a new genus by means of a molecular approach to accommodate $P$. pandaliformis due to the proximity of the species to the genus Macrobrachium Spence Bate, 1868. Despite the recent discussion proposed by these authors, the wide distribution of the species, and the increasing use of the shrimp in aquarium trading (LRP Paschoal pers. observ.), studies focusing on the biology of $P$. pandaliformis are scarce, especially in freshwater environments. In estuarine environments, some of these works include: CoELHO 
(1964), who descriptively discussed a few ecological aspects such as feeding, grooming and fecundity; Lima \& OsHiro (2002), who briefly described the reproductive biology of this shrimp, and observed a population dominated by females with continuous reproductive activity; MORTARI et al. (2009), who studied the reproductive biology of two populations with no sex predominance (1:1 sex ratio), and observed both seasonal (non-continuous) and continuous reproductive activity throughout the year; and Rosa et al. (2015), who discussed ecological and reproductive aspects, and described a population that is dominated by large and heavy females with higher abundances during warmer months and seasonal reproductive activity. Until this moment, only two studies were conducted in freshwater environments, namely PASCHOAL et al. (2013a), who observed the association of this shrimp with macrophytes, their habitat preferences, and their uses by males and females; and PASCHOAL et al. (2013b), who estimated the sexual maturity and assessed the relative growth variability between sexes, thus showing that females were larger and heavier than males.

Palaemon pandaliformis exhibits different reproductive and ecological patterns depending on the sampled environment. In this study, we present the population biology, growth patterns and reproductive aspects of $P$. pandaliformis in a neotropical river. We also assessed the effects of rainfall on the recruitment and reproduction of $P$. pandaliformis. These population biology and reproductive aspects were compared to those available in the literature for estuarine populations in order to focus on intraspecific variability.

\section{MATERIAL AND METHODS}

\section{Study site and sampling}

Rio Salsa $\left(15^{\circ} 42^{\prime} \mathrm{S}, 38^{\circ} 59^{\prime} \mathrm{W}\right)$ is a neotropical river located in the south of the state of Bahia, northeastern Brazil. It is considered one of the main tributaries of Rio Pardo, and its watershed covers an area of $30360 \mathrm{~km}^{2}$ (Fig. 1). The studied river is subjected to untreated domestic sewage discharge, artisanal and commercial fish and shrimp fisheries, tourism and water sports activities (PASCHOAL et al. 2013a,b).

Samples were collected monthly between September 2009 and August 2010, at nine collection sites along a reach of Rio Salsa $(\sim 2.5 \mathrm{~km})$ located in the municipality of Canavieiras (Fig. 1). The studied reach was on average 30 meters wide and 5 meters deep. Shrimps were collected during the day with a hand net $(0.5 \mathrm{~mm}$ mesh) that was swept through marginal vegetation and macrophyte banks for 20 minutes. The sampling sites were selected according to the vegetative extension, abundance, and longevity of the macrophyte patches, and approximately 300 meters apart. The macrophytes banks comprised three patches of Brachiaria sp. (Trin.) Griseb., 1853 (P1, P2 and P6), three patches of Juncus sp. (L.) (P3, P4 and P5), and three patches of Eichhornia crassipes (Mart.) Solms (P7, P8 and P9). The sampling sites are located $\sim 11 \mathrm{~km}$ from the estuary area.

Rainfall data in the municipality of Canavieiras were obtained from the Real Time Monitoring Programme of the Northeastern Region (PROCLIMA).

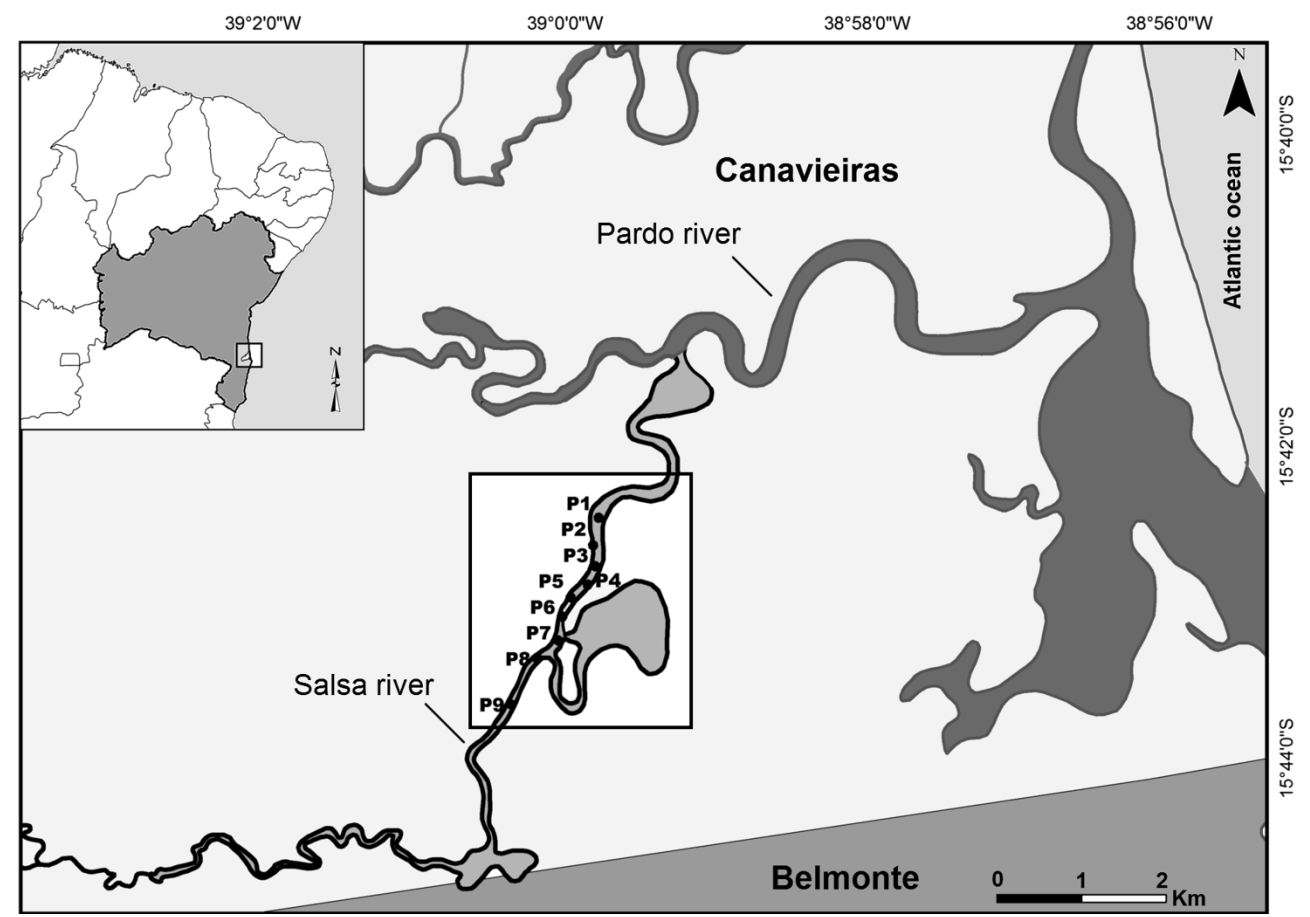

Figure 1. Location of sampling sites in the study area. 


\section{Measurements}

After collection, the samples were preserved in $70 \%$ ethanol and transported to the laboratory. The samples were identified according to Melo (2003). Sex was determined by examining the endopodite shape of the first pair of pleopods and by inspecting the appendix masculina (presence or absence) on the endopodite of the second pair of pleopods (BAUER 2004). Individuals with carapace length smaller than the smallest identified male were counted as not sexable (PAschOAL et al. 2013b). These individuals were not used in the analysis. Permissions were granted by the ICMBio/SISBIO (SISBIO \#36210-1). Voucher specimens were deposited in the Museu de Zoologia da Universidade de São Paulo (MZUSP), and catalogued as MZSP 28.313.

The shrimps were measured using a stereomicroscope with an imagery system. Images were analysed using Image ${ }^{\circledR}$ software version 1.45 . The samples were measured according to Anger \& Moreira (1998) and Nazari et al. (2003). For both sexes we measured carapace (CL) and total length (TL). For ovigerous females we also measured the three first abdominal pleuras length (PL), second abdominal pleura height (PH), and distance between right and left second abdominal pleuras (PD). Individual wet weight $(\mathrm{W})$ was calculated using a precision scale $(0.001 \mathrm{~g})$.

\section{Sex ratio and recruitment}

We obtained total, monthly and size class proportions for males and females. The Chi-squared $\left(\chi^{2}\right)$ test was used to determine whether sex ratio differed from the expected 1:1 proportion.

Individuals with CL equal or smaller than $4.53 \mathrm{~mm}$ were considered immature (i.e. recruits, as established by PASCHOAL et al. 2013b). Recruitment patterns were determined by observing modal peaks of juveniles during the studied period (i.e. higher percentage of recruits per month). We also assessed whether rainfall was associated to the frequency of immature individuals using Pearson correlation.

\section{Growth and age}

Total and monthly population structure of $P$. pandaliformis were analysed by determining the distribution frequency of carapace length (CL) using classes with $1.0 \mathrm{~mm}$ interval for both sexes. Normality of frequency distribution was evaluated using the Shapiro-Wilk test, and homoscedasticity was calculated using Levene's test. However, the normality (W-Statistic: 0.99, $\mathrm{p}<0.001)$ and homoscedasticity $\left(\mathrm{F}_{1,309:} 4147, \mathrm{p}<0.001\right)$ assumptions were not satisfied. Average CL values obtained throughout the year for males and females were compared using a non-parametric Mann-Whitney U-test.

Growth was estimated by observing modal shifting from September 2009 to August 2010. Modes for males and females were identified using PeakFit $4.12^{\circ}$ (Systat Software Inc, Richmond, CA), which contains an algorithm that estimates normal distribution in length group frequencies and identifies a central parameter corresponding to mode (FonsECA \& D'INCAO 2003). The central parameters and initial graphic outline of the growth curve were selected according to the points with a lower standard error (SE) and the highest coefficient of determination $\left(\mathrm{r}^{2}\right)$.

Cohorts were obtained manually and selected to design the growth curves. The Von Bertalanffy growth (VBG) equation, which estimates the size of the individual in relation to age when growth has a non-seasonal pattern, was: $\mathrm{L}_{\mathrm{t}}=\mathrm{L}_{\infty}\left[1-\mathrm{e}^{-\mathrm{K}(\mathrm{t}-\mathrm{to})}\right]$, where: $L_{t}$ is length (mm) for a given age $t, L_{\infty}$ is the maximum theoretical length that the species can reach (i.e. asymptotic size), $\mathrm{K}$ is growth curve inclination or growth constant/rate (mm/year), $\mathrm{t}$ is age of individuals, and $t_{0}$ is age of the animal at birth $\left(\mathrm{L}_{\mathrm{t}}: 0\right)$. To estimate growth parameters, all the cohorts were fitted to the VBG model using an automated least squares method (SOLVER, software MS Excel) (BAEZA et al. 2013).

Growth parameters and curves were calculated separately for each sex. The 95\% confidence and the prediction intervals of each curve were also calculated. Lifespan was obtained using the inverted VBG formula altered by D'INCAO \& FonsECA (1999) for both sexes.

Pauly \& Munro (1984) stated that the growth performance index $\left(\Phi^{\prime}\right)$ is more appropriate to compare growth between sexes than $\mathrm{L}_{\infty}$ and $\mathrm{K}$ individually since these parameters are correlated and less robust. Thus, $\Phi^{\prime}$ was calculated with the equation: $\Phi^{\prime}=\log \mathrm{K}+2 \log \mathrm{L}_{\infty}$.

Moreover, growth patterns estimated for this species were compared with available studies involving shrimps in the Palaemon genus. For this comparison, we only selected the VBG studies published before the revision of the genera proposed by De Grave \& Ashelby (2013). Consequently, junior synonyms of Palaemon (former genus Palaemonetes Heller, 1869, Exopalaemon Holthuis, 1950 and Coutierella Sollaud, 1914) were not assessed.

\section{Reproduction}

Ovigerous females were classified into three stages according to the embryonary development stage: initial (I) - more than $2 / 3$ of the egg volume occupied by yolk, without visible eye pigmentation, and an embryo with little or no differentiation; intermediate (II) - eye pigmentation formed and embryo differentiated, with yolk occupying more than $1 / 3$ of the egg volume; and final (III) - well-developed eye pigmentation, appendix differentiation in final phase and yolk occupying less than 1/3 of egg volume (ANGer \& Moreira 1998).

Subsequently, the frequency of ovigerous females was obtained for every month considering two different groups: females carrying eggs with no eye (stage I), and with eye pigmentation (stages II and III), thus allowing the observation of modal peaks. A correlation coefficient was used to evaluate the association of rainfall on the frequency of ovigerous females.

Brood pouch volume (BPV) of the ovigerous females was estimated considering PL, PH and PD (NAZARI et al. 2003). The relative growth of CL, TL and W vs. BPV was also determined (see "Measurements" section for further details). Power functions were linearized by log transformation (base 10), and allometric constants (b) were tested using a one-sample t-test to assess whether observed coefficients were different from 3 , considering 
it is a three dimensional variable. These functions were used to determine relative growth patterns.

Fecundity was assessed by directly counting the eggs of 180 ovigerous females ( 15 females were randomly selected per month). Only females with eggs in the initial phase of development (stage I) were analysed given the possibility of potential egg loss during incubation (NAZARI et al. 2003). The correlation coefficient was calculated to evaluate the association between fecundity and values of CL, TL, W, and BPV.

Reproductive output ( $\mathrm{RO}$ ) was determined by means of weight of the female $\left(\mathrm{W}_{\mathrm{d}}\right)$ and egg mass $\left(\mathrm{EMW}_{\mathrm{d}}\right)$ dehydrated in an oven at $70^{\circ} \mathrm{C}$ for 48 hours, weighed on a precision scale $(0.001$ $\mathrm{g})$, and estimated using the formula: $\mathrm{RO}=\left(\mathrm{EMW}_{\mathrm{d}} / \mathrm{W}_{\mathrm{d}}\right) \times 100$

A subsample of 50 eggs in each embryonary stage was used to calculate individual egg volume. Long axis (l) and short axis (h) of each egg were measured under a stereomicroscope coupled to an imaging system (Zeiss/Axiovision - 40X). The eggs were treated as ellipsoids, and volume (VO) was calculated using the following equation (Odinetz-Collart \& RABelo 1996): $\mathrm{VO}=\left(\varpi \mathrm{lh}^{2}\right) / 6$.

As the normality assumption was not satisfied (W-Statistic: 0.92, $\mathrm{p}<0.001$ ), the Kruskal-Wallis (KW) non-parametric analysis of variance was used to compare the average egg volume between stages, followed by a post-hoc comparison of means using the Tukey test.

\section{RESULTS}

\section{Sex ratio and recruitment}

A total of 4151 individuals ( 2860 males and 1291 females) were analysed. Total sex ratio $(\mathrm{M}: \mathrm{F})$ was 2.21:1 $\left(\chi^{2}=295.91, \mathrm{df}=1\right.$, $\mathrm{p}<0.001)$. Males were predominant in all monthly collections, with sex ratio ranging from 1.20:1 $\left(\chi^{2}=0.64, \mathrm{df}=1, \mathrm{p}=0.14-\right.$ Jan./2010) to 3.41:1 $\left(\chi^{2}=57.42\right.$, df $=1, \mathrm{p}<0.001-$ May/2010) (Fig. 2). The sex ratio analysis of size classes showed a pattern in which the males were significantly concentrated in the intermediary size classes, and females were concentrated in the upper size classes (Fig. 3).

Around 13\% (N: 531) of the captured individuals were immature. The peak of recruitment occurred in March and April 2010 (Autumn), when there was a higher proportion of juveniles in the population (Fig. 4). There was a weak and non-significant positive correlation between recruitment and rainfall $(\mathrm{r}=0.33, \mathrm{p}=0.30)$.

\section{Growth and Age}

The CL of females varied between 1.22 and $13.17 \mathrm{~mm}$ (TL: 6.3-36.4 $\mathrm{mm}$ ) and the CL of males varied between 1.78 and 9.25 mm (TL: 8.12-32.4 mm). Females ( $\bar{x} \pm$ SD: $6.31 \pm 1.51 \mathrm{~mm} \mathrm{CL})$ were significantly larger than males $(\bar{x} \pm$ SD: $5.55 \pm 0.95 \mathrm{~mm}$ CL) (U: 1211385, p < 0.001) (Fig. 5).

The frequency distribution of size class for both sexes throughout the year complied with a polymodal pattern (remarkably in female shrimps) (Fig. 6). Estimated modal peaks and selected cohorts, with the determination of the four cohorts for both sexes, are shown in Fig. 7. It was possible to observe that the female cohorts reached larger maximum sizes than the male cohorts.

The growth equations indicated that the females $\left(\mathrm{CL}_{\infty}: 13.2\right.$, $\mathrm{TL}_{\infty}: 38.8 \mathrm{~mm}$ ) grew faster and reached larger sizes than the males $\left(\mathrm{CL}_{\infty}: 9.3, \mathrm{TL}_{\infty}: 27.5 \mathrm{~mm}\right)$. Although the females reached larger sizes, their growth rate $(\mathrm{K})$ was lower than that of the males. The higher $\Phi^{\prime}$ values registered for the females explain this pattern, which is probably a pattern of the genus Palaemon (Table 1). Furthermore, maximum estimated lifespan was greater for the females (16 months) than for the males (13 months) (Figs. 7-8).

\section{Reproduction}

Of the 1291 collected females, 452 (35\%) were ovigerous. Two peaks were recorded, with an initial peak in January (45\%) and February (51\%) 2010 (Summer), and a second peak in July (53\%) and August (63\%) 2010 (Winter) (Fig. 9).
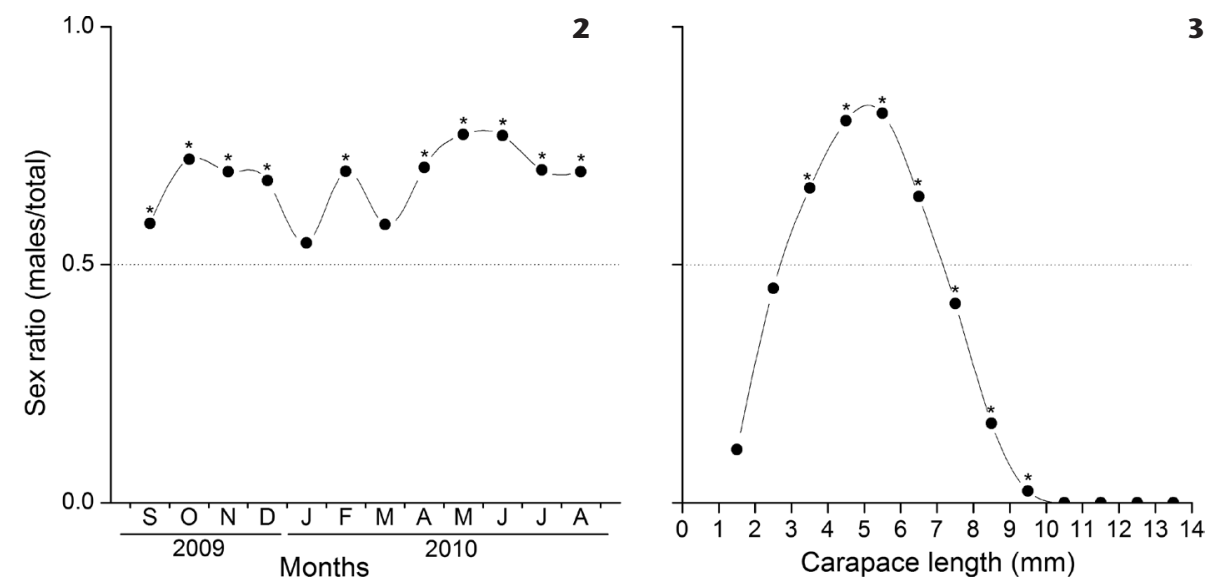

Figures 2-3. Sex ratio (male/total) of Palaemon pandaliformis collected from September 2009 and August 2010 in Rio Salsa, Canavieiras, Bahia, Brazil. (2) Monthly fluctuations. (3) Anomalous probability curve derived from a year sampling collection. * Statistically significant at $p \leq 0.05$. 


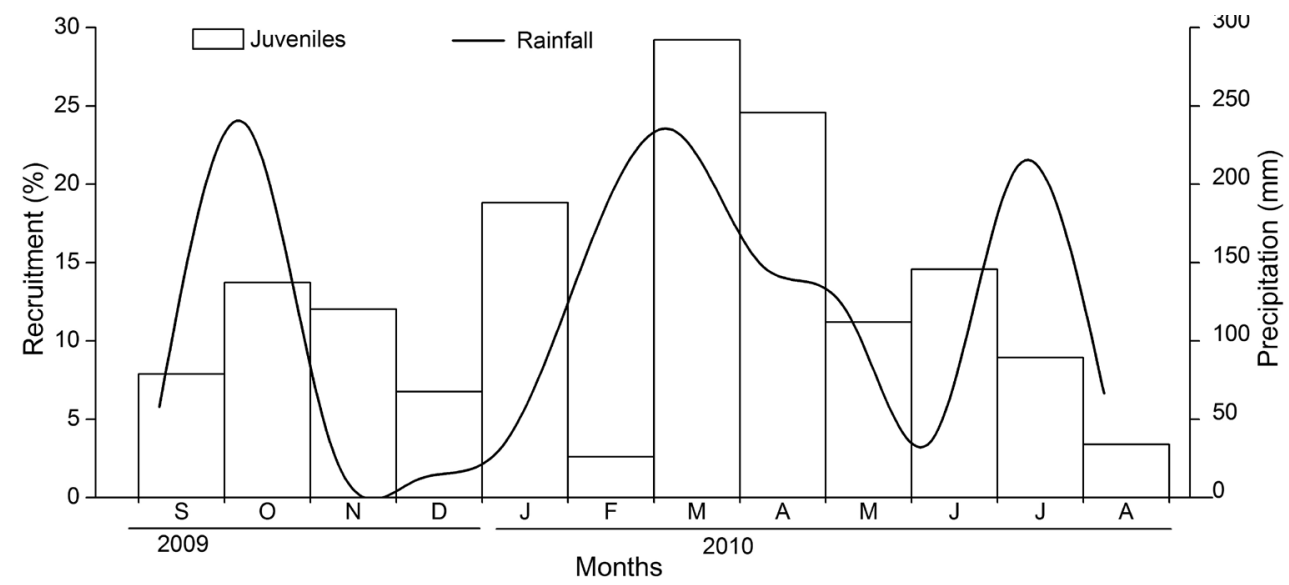

Figure 4. Recruitment pattern of Palaemon pandaliformis and monthly precipitation recorded from September 2009 and August 2010 in Rio Salsa, Canavieiras, Bahia, Brazil.

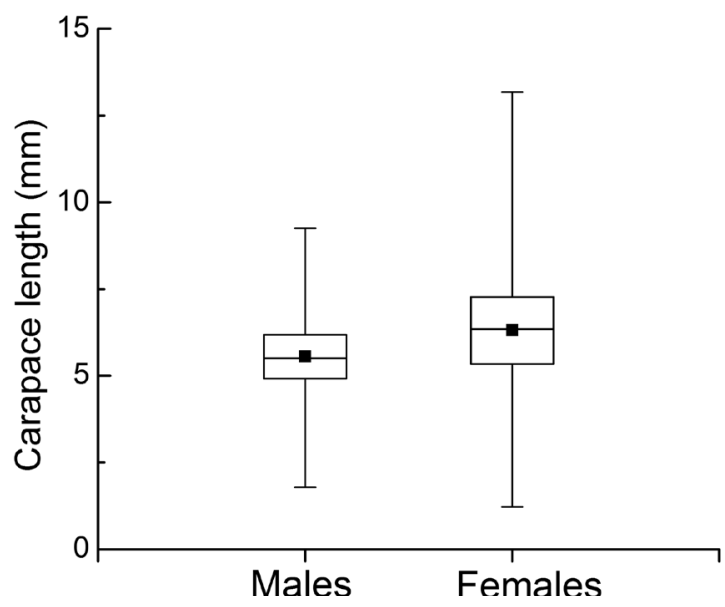

Table 1. Von Bertalanffy growth parameters estimated from the length frequency distribution analysis for males and females of $\mathrm{Pa}$ laemon pandaliformis and a comparison between studies involving shrimps in the Palaemon genus. $\left(\mathrm{L}_{\infty}\right)$ asymptotic carapace length $(\mathrm{mm}),(\mathrm{K})$ growth coefficient $\left(\right.$ year $\left.^{-1}\right),\left(\mathrm{t}_{0}\right)$ age at zero length, $\left(\Phi^{\prime}\right)$ growth performance index, (ni) data not informed, $\left(^{*}\right)$ values estimated from the data set of the authors.

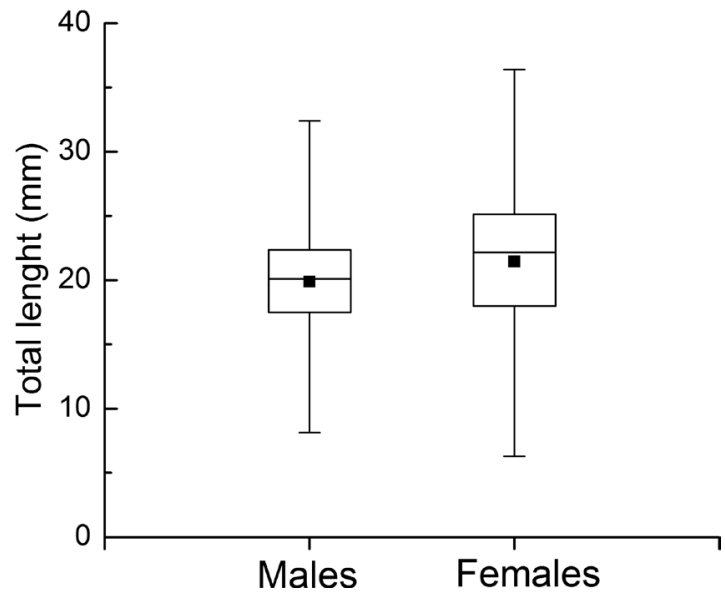

Figure 5. Minimum, maximum (whiskers), median (horizontal line) and mean (black square) carapace and total length values for males and females of Palaemon pandaliformis collected from September 2009 and August 2010 in Salsa River, Canavieiras, Bahia, Brazil.

\begin{tabular}{|c|c|c|c|c|}
\hline \multirow{2}{*}{ Species } & \multirow{2}{*}{ Reference } & \multirow{2}{*}{ Parameter } & \multicolumn{2}{|c|}{ Sex } \\
\hline & & & Male & Female \\
\hline \multirow{4}{*}{ P. adspersus } & \multirow{4}{*}{ BıLGIN et al. 2009a } & $\mathrm{L}_{\infty}(\mathrm{mm})$ & 49.63 & 62.79 \\
\hline & & $\mathrm{K}\left(\right.$ year $\left.^{-1}\right)$ & 1.08 & 1.19 \\
\hline & & $\mathrm{t}_{0}$ (year) & 0.38 & 0.60 \\
\hline & & $\Phi^{\prime}$ & 3.43 & 3.67 \\
\hline \multirow{4}{*}{ P. elegans } & \multirow{4}{*}{ BILGIN et al. $2009 \mathrm{~b}$} & $\mathrm{~L}_{\infty}(\mathrm{mm})$ & 42.28 & 47.88 \\
\hline & & K (year-1) & 1.39 & 1.21 \\
\hline & & $\mathrm{t}_{0}$ (year) & 0.80 & 0.98 \\
\hline & & $\Phi^{\prime}$ & 3.40 & 3.44 \\
\hline \multirow{4}{*}{ P. gravieri } & \multirow{4}{*}{ ARAKI \& HAYASHI 2002} & $\mathrm{~L}_{\infty}(\mathrm{mm})$ & 10.46 & 24.47 \\
\hline & & K $\left(\right.$ year $\left.^{-1}\right)$ & 3.86 & 0.68 \\
\hline & & $\mathrm{t}_{0}$ (year) & 0.01 & 0.41 \\
\hline & & $\Phi^{\prime}$ & $2.63^{*}$ & $2.61^{*}$ \\
\hline \multirow{4}{*}{ P. longirostris } & \multirow{4}{*}{ CARTAXANA 2003} & $\mathrm{~L}_{\infty}(\mathrm{mm})$ & 11.68 & 16.32 \\
\hline & & $\mathrm{K}\left(\right.$ year $\left.^{-1}\right)$ & 0.62 & 0.51 \\
\hline & & $\mathrm{t}_{0}$ (year) & 0.49 & 1.42 \\
\hline & & $\Phi^{\prime}$ & 1.93 & 2.13 \\
\hline \multirow{4}{*}{ P. pandaliformis } & \multirow{4}{*}{ Present study } & $\mathrm{L}_{\infty}(\mathrm{mm})$ & 9.30 & 13.20 \\
\hline & & $\mathrm{K}\left(\right.$ year $\left.^{-1}\right)$ & 4.32 & 3.51 \\
\hline & & $\mathrm{t}_{0}$ (year) & 0.03 & 0.37 \\
\hline & & $\Phi^{\prime}$ & 2.57 & 2.79 \\
\hline \multirow{4}{*}{ P. paucidens } & \multirow{4}{*}{ KIM et al. 2008} & $\mathrm{~L}_{\infty}(\mathrm{mm})$ & 14.51 & 17.75 \\
\hline & & K (year-1) & 0.55 & 0.57 \\
\hline & & $\mathrm{t}_{0}$ (year) & ni & $\mathrm{ni}$ \\
\hline & & $\Phi^{\prime}$ & 2.06 & 2.25 \\
\hline \multirow{4}{*}{ P. xiphias } & \multirow{4}{*}{ Guerao et al. 1994} & $\mathrm{~L}_{\infty}(\mathrm{mm})$ & 50 & 70 \\
\hline & & K (year-1) & 1.57 & 1.92 \\
\hline & & $\mathrm{t}_{0}$ (year) & 0.31 & 0.15 \\
\hline & & $\Phi^{\prime}$ & $3.59^{*}$ & $3.97^{*}$ \\
\hline
\end{tabular}




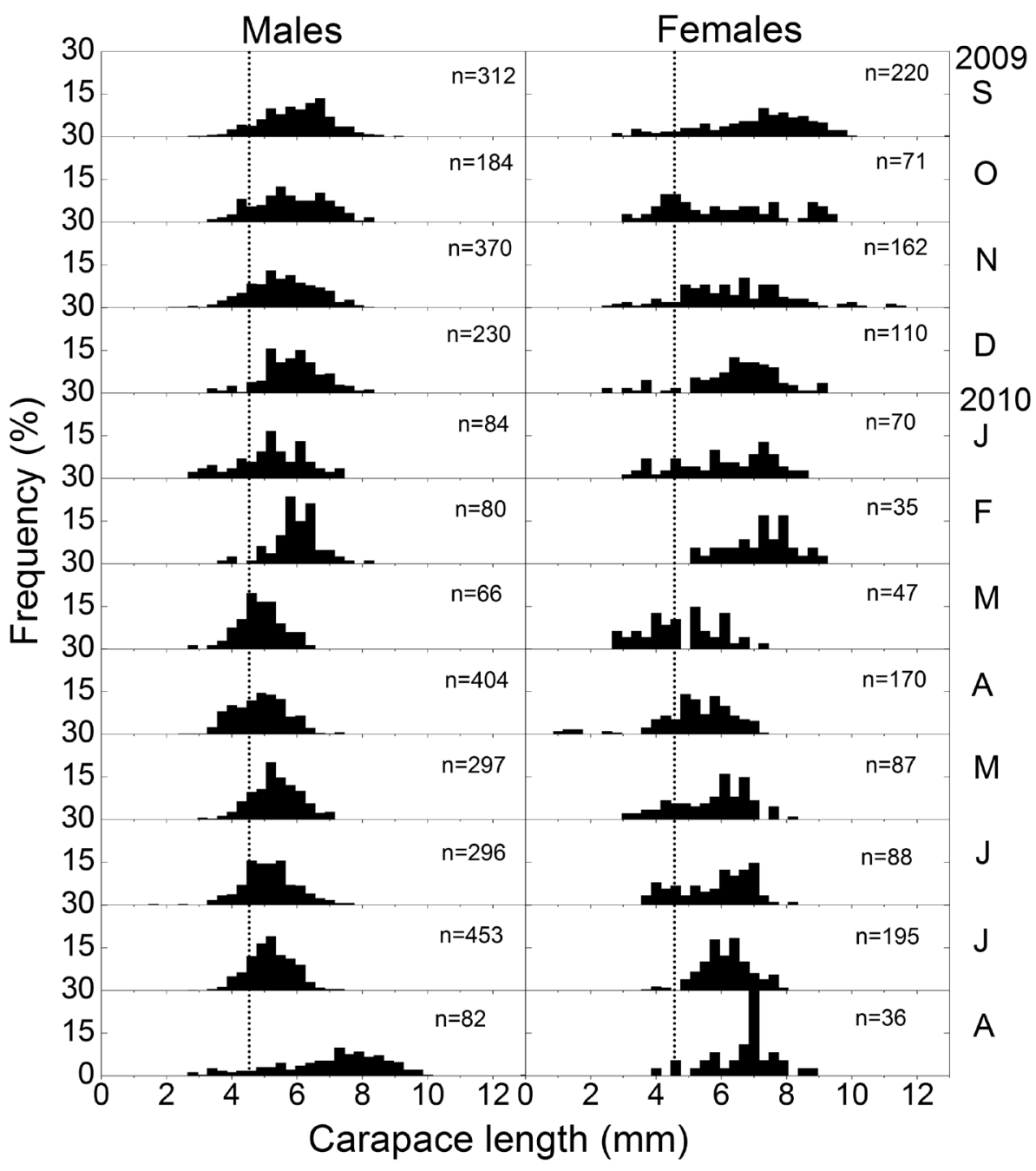

Figure 6. Monthly length frequency distribution of males and females of Palaemon pandaliformis collected from September 2009 and August 2010 in Rio Salsa, Canavieiras, Bahia, Brazil. Dotted line at $4.53 \mathrm{~mm}$ was drawn for illustrative purposes, indicating recruitment of small individuals into the population, according to PASCHOAL et al. (2013b).

The lowest proportion of ovigerous females was $11.76 \%$ (April 2010) and the highest was 63.89\% (August 2010) (Fig. 9). Around $80 \%$ of the ovigerous females had eggs in stage I, $18 \%$ in stage II, and only $2 \%$ in stage III. Females with eggs in the initial stage of development were predominant during all the studied months except for March 2009. There was a slight decrease in the number of ovigerous females as rainfall increased $(r=-0.21, p=0.52)$.

Average fecundity registered for $P$. pandaliformis was 139 eggs per female, which is within the margin recorded for the specimens collected in other locations in Brazil (Table 2). The CL of ovigerous females varied from 3.80 to $11.53 \mathrm{~mm}(\bar{x} \pm \mathrm{SD}$ : $7.18 \pm 1.11)$ and BPV ranged from 5.60 to $24.01 \mathrm{~mm}^{3}(\bar{x} \pm$ SD: $11.81 \pm 3.24$ ), presenting a negative allometry. Negative allometries were also observed when regressing BPV on TL or $\mathrm{W}$,
Table 2. Comparison of fecundity in Palaemon pandaliformis between studies from different latitudes.

\begin{tabular}{lll}
\hline Latitude & Fecundity amplitude $(\overline{\mathrm{X}} \pm \mathrm{SD})$ & \multicolumn{1}{c}{ Authors } \\
\hline $08^{\circ} 02^{\prime} \mathrm{S}$ & 290 & COELHO (1964) \\
$15^{\circ} 42^{\prime} \mathrm{S}$ & $34-250(139 \pm 48)$ & Present study \\
$22^{\circ} 56^{\prime} \mathrm{S}$ & $40-270(137)$ & LIMA \& OSHIRO (2002) \\
$23^{\circ} 20^{\prime} \mathrm{S}$ & $75-207(130 \pm 25)$ & MORTARI et al. (2009) \\
$23^{\circ} 29^{\prime} \mathrm{S}$ & $103-412(189 \pm 53)$ & MORTARI et al. (2009) \\
$23^{\circ} 49^{\prime} \mathrm{S}$ & $102-375$ & ANGER \& MOREIRA (1998) \\
\hline
\end{tabular}

which indicates that BPV tends to grow at a greater proportion than other parts of the body (Table 3 ).

Fecundity (Fec) varied from 34 to 250 eggs ( $\bar{x} \pm$ SD: $139 \pm$ 48). Relations Fec vs. BPV, Fec vs. CL, Fec vs. TL, and Fec vs. W 


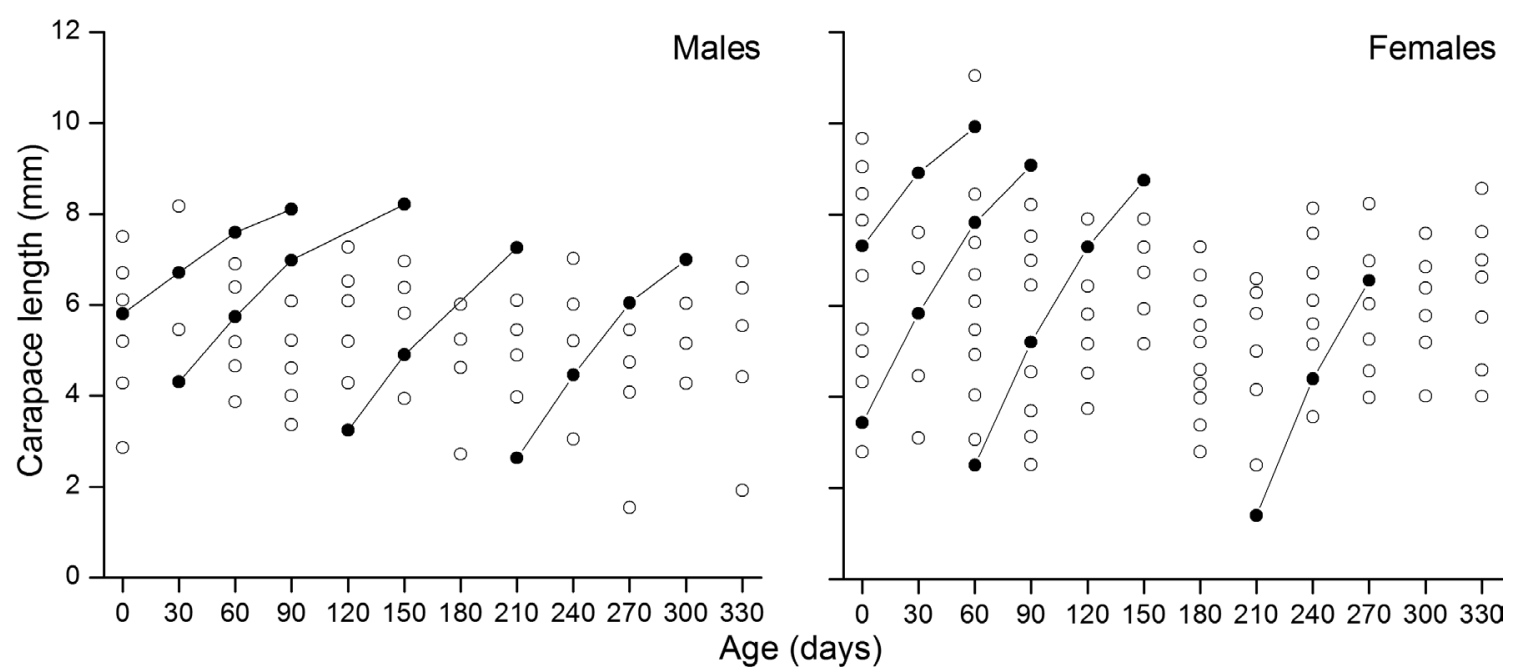

Figure 7. Modal dispersion and selected cohorts for males and females of Palaemon pandaliformis collected from September 2009 and August 2010 in Rio Salsa, Canavieiras, Bahia, Brazil.
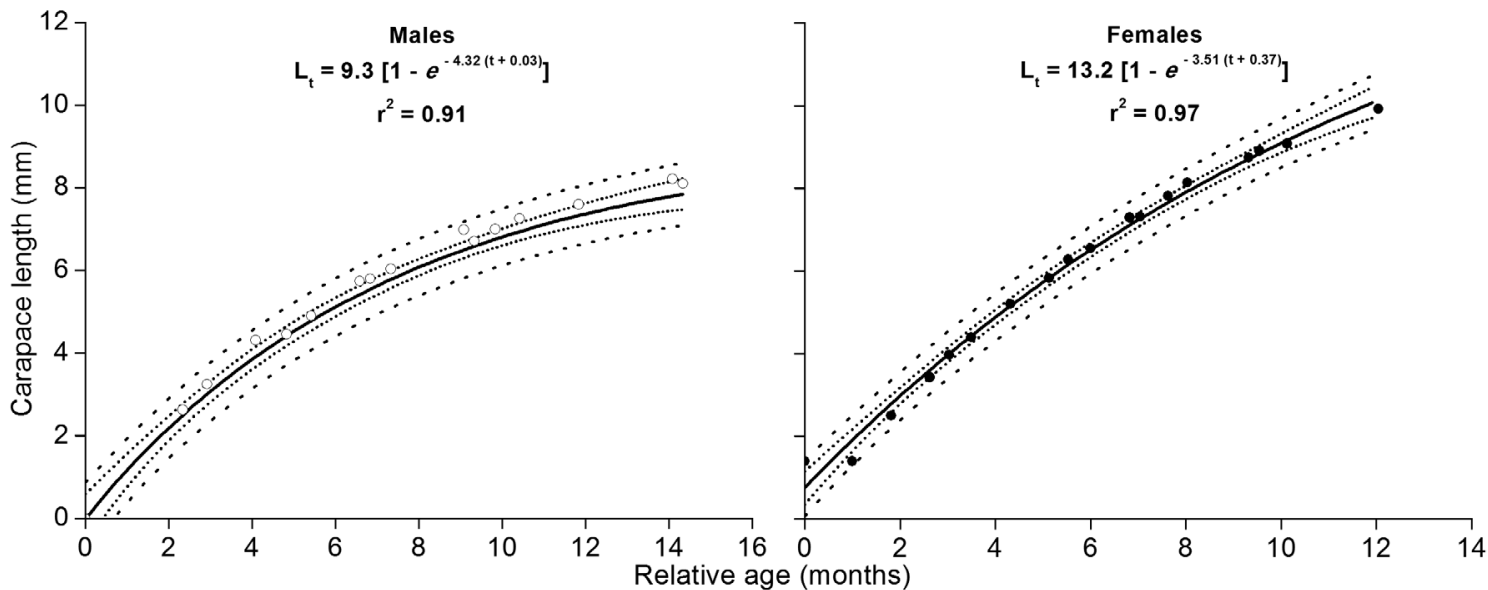

Figure 8. Von Bertalanffy growth curves for male and female data of Palaemon pandaliformis based on monthly length-frequency distribution from September 2009 and August 2010 in Rio Salsa, Canavieiras, Bahia, Brazil. Center line: mean; dotted lines: confidence intervals (95\%); dashed lines: prediction interval (95\%). Individual points represent modal carapace length (CL) derived from size-frequency distributions.

Table 3. Relationship between brood pouch volume (BPV) and morphometric data in ovigerous females of the Palaemon pandaliformis sampled in Rio Salsa, Canavieiras, Bahia, Brazil. (CL) Carapace length, $(T L)$ total length, $(W)$ total weight, $\left(r^{2}\right)$ coefficient of determination, $(A)$ allometry, $\left(^{*}\right)$ statistically significant at $p \leq 0.05$.

\begin{tabular}{llcccc}
\hline Variables & Linear regression & $\mathrm{N}$ & $\mathrm{r}^{2}$ & $\mathrm{t}$ & $\mathrm{A}$ \\
\hline $\mathrm{CL}(\mathrm{mm})$ & $\mathrm{CL}: 0.09^{*} \mathrm{BPV}+5.58$ & 179 & 0.20 & $-10.70^{*}$ & - \\
$\mathrm{TL}(\mathrm{mm})$ & $\mathrm{TL}: 0.48^{*} \mathrm{BPV}+19.65$ & 179 & 0.34 & $-10.61^{*}$ & - \\
$\mathrm{W}(\mathrm{g})$ & $\mathrm{W}: 13.93^{*} \mathrm{BPV}+83.63$ & 179 & 0.58 & $-40.20^{*}$ & - \\
\hline
\end{tabular}

showed that the fecundity of females tends to increase as they increase in body size (Figs. 10-13).
In this study, average total egg mass corresponded to $21 \%$ of female weight, which is within the average reproductive output (RO) range of the studied Palaemonidae. Other studies conducted with Palaemonids observed RO values ranging from 12 to $27 \%$ (Table 4 ).

The eggs of $P$. pandaliformis were attached by chorion filaments and surrounded with mucus, thus forming a compact mass that exceeded the lower limit of the abdominal pleura. There was a significant increase in size due to growth of their axes, with the exception of the short axis from stage I to stage II (decrease of $0.13 \%$ in size). There was an increase in the short axis of stage II to stage III of $12.92 \%$, and for long axes of $4.64 \%$ from stage I to stage II, and of $12.89 \%$ from stage II to stage III. Average volumes 


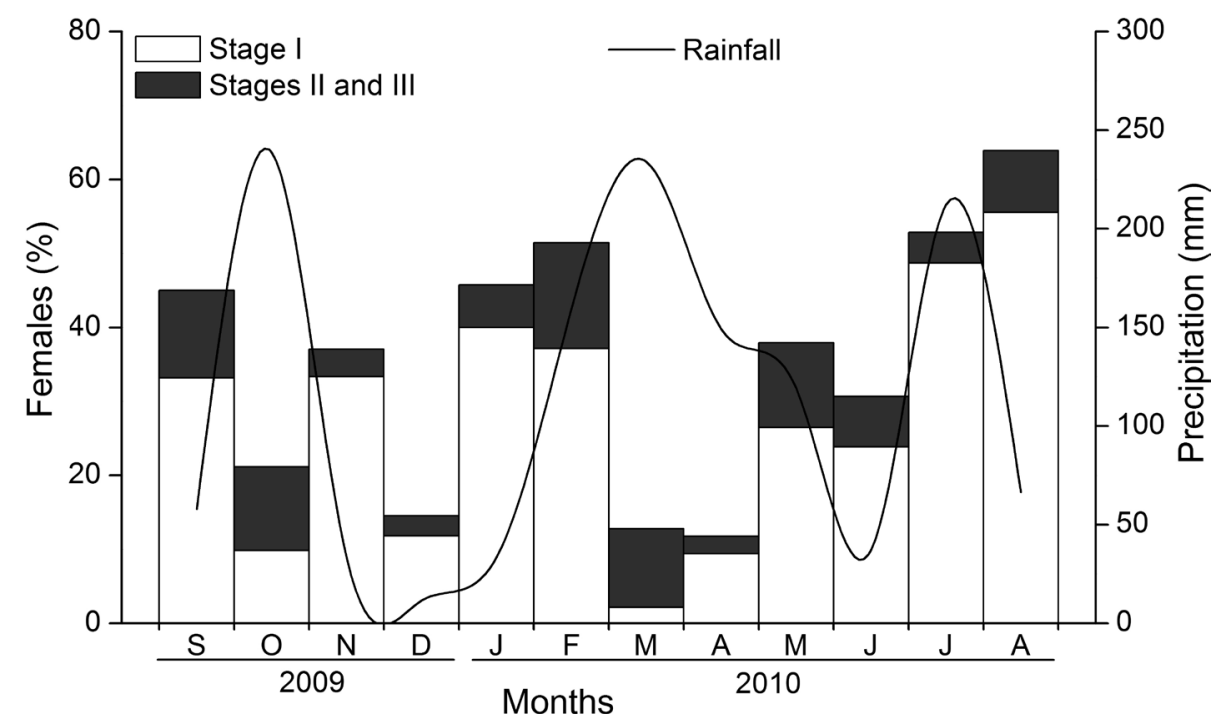

Figure 9. Monthly changes in the percentage occurrence of Palaemon pandaliformis female with non-eye (Stage I) and eyed eggs pigmentation (Stage II and III), and precipitation recorded from September 2009 and August 2010 in Rio Salsa, Canavieiras, Bahia, Brazil.

showed an apparent increase of $3.29 \%$ from stage I to II, and of $34.41 \%$ from stage II to III (KW $=54.72, \mathrm{df}=2, \mathrm{p}<0.001)$ (Table 5 ).

Table 4. Comparison of reproductive output (RO) between studies of Palaemonid shrimps from different habitats. (E) Estuarine, (F) freshwater, (M) marine.

\begin{tabular}{lccl}
\hline \multicolumn{1}{c}{ Species } & Habitat & RO & \multicolumn{1}{c}{ References } \\
\hline Macrobrachium acanthurus & F/E & 0.19 & ANGER \& MOREIRA (1998) \\
Macrobrachium olfersi & F/E & 0.22 & ANGER \& MOREIRA (1998) \\
Palaemon elegans & $\mathrm{M}$ & 0.12 & JANAS \& MAŃKUCKA (2010) \\
Palaemon modestus & $\mathrm{F}$ & 0.17 & OH et al. (2002) \\
Palaemon northropi & $\mathrm{M}$ & 0.14 & ANGER \& MOREIRA (1998) \\
Palaemon pandaliformis & $\mathrm{F} / \mathrm{E}$ & 0.19 & ANGER \& MOREIRA (1998) \\
Palaemon pandaliformis & $\mathrm{F} / \mathrm{E}$ & 0.21 & Present study \\
Palaemon paucidens & $\mathrm{F}$ & 0.27 & KIM et al. (2008) \\
\hline
\end{tabular}

Table 5. Axes lengths and volumes of three stages of Palaemon pandaliformis eggs. Mean $( \pm S D)$. Values with different letters are significantly different $(p<0.05)$.

\begin{tabular}{cccc}
\hline \multirow{2}{*}{ Stages } & \multicolumn{2}{c}{ Axis $(\mathrm{mm})$} & \multirow{2}{*}{ Volume $\left(\mathrm{mm}^{3}\right)$} \\
\cline { 2 - 3 } & Short & Long & \\
\hline I & $0.577( \pm 0.070)$ & $0.724( \pm 0.074)$ & $0.129( \pm 0.038)^{\mathrm{a}}$ \\
II & $0.576( \pm 0.073)$ & $0.760( \pm 0.090)$ & $0.133( \pm 0.035)^{\mathrm{a}}$ \\
III & $0.662( \pm 0.075)$ & $0.872( \pm 0.103)$ & $0.203( \pm 0.058)^{\mathrm{b}}$ \\
\hline
\end{tabular}

\section{DISCUSSION}

\section{Sex ratio and recruitment}

Males were predominant in the studied area (2.21:1), although FisHER (1930) points out that natural selection favours the production of offspring at a 1:1 (M:F) proportion and that the cost of producing each sex is equal. However, WiLson \& Pianka (1963) stated that sexual proportions can be biased due to a series of factors (e.g., behaviour, migration, mortality and growth rates), which eventually cause a significant deviation in the sex ratio of a population. The results obtained here differ significantly from those presented by Lima \& Oshiro (2002) and Mortari et al. (2009), who studied estuarine populations of $P$. pandaliformis from rivers of Rio de Janeiro and São Paulo (southeastern Brazil) and recorded sex ratios of 1:1.57 and 1:1.19-1:1.34, respectively, which indicates a slight significant predominance of females. Rosa et al. (2015) also recorded a high predominance of females (1:5.7) in a subtropical salt marsh in southern Brazil (state of Paraná).

WeNnER (1972) states that the deviation from a 1:1 (M:F) proportion is common in crustaceans, and described four types of sex ratio patterns as a function of size (i.e. standard, reversal, intermediate and anomalous) for a wide range of crustaceans. The sex ratio pattern that best fit the studied population is the "anomalous pattern". As observed by WenNER (1972) in other crustaceans, the proportion of the population of $P$. pandaliformis in the smaller-sized classes was approximately 1:1 (M:F), while males were concentrated in the intermediate-sized and females were concentrated in the large-sized classes, considering that females only occur in the last four classes.

The shorter lifespan of males in comparison with females (see "Growth and age" results section for further details) would explain the predominance of these intermediate-sized classes and the lower average sizes reached by males. GAvio et al. (2006) analysed a population of the caridean shrimp Crangon franciscorum Stimpson, 1856 and observed a higher frequency and smaller sizes for males during the first year of life, whereas the 

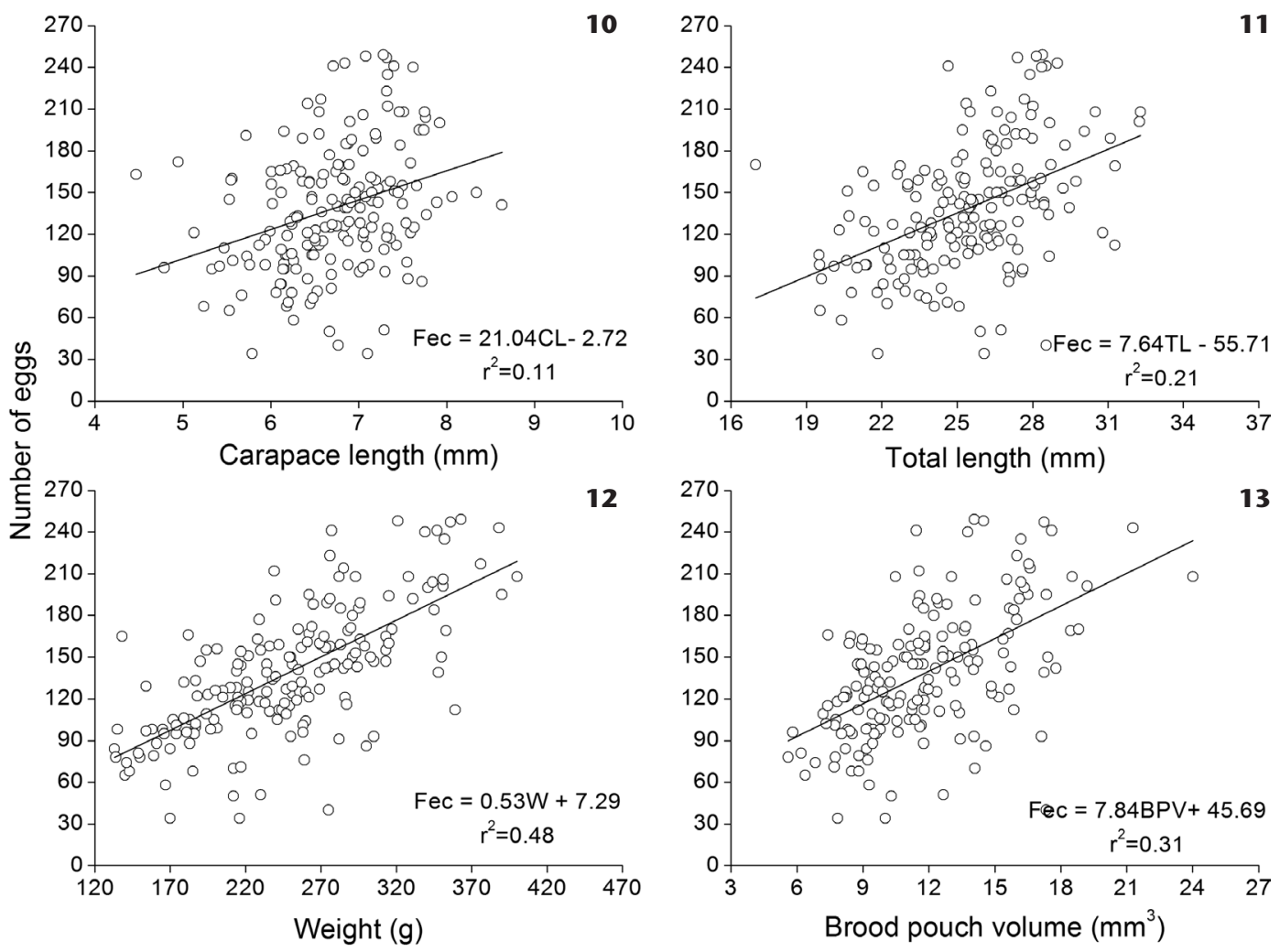

Figures 10-13. Relationship between fecundity (Fec - number of eggs) and carapace length (10), total length (11), weight (12) and brood pouch volume (13) for Palaemon pandaliformis females collected from Rio Salsa, Canavieiras, Bahia, Brazil.

females continued to grow. These authors suggest that males have a shorter lifespan and disappear from the population in the second year, while the females (especially ovigerous ones) remain. They attribute death as the cause of the reduced number of male individuals in larger size classes.

Amphidromous juvenile shrimps (immature individuals) must find a river mouth and migrate upstream to the environment of adults. These recruits can be captured during their migration to colonize or re-colonize riverine habitats. Commonly, the low speed of the water flow in dry seasons benefits the presence of recruits due to low amount of energy required to move upstream associated to few potential obstacles for re-colonization (e.g., reduced downstream drift) (BAUER 2004, 2013). There were no recruitment data for $P$. pandaliformis in other locations, which prevents any comparisons.

However, we recorded an inverted pattern with greater recruitment occurring in higher water flow periods, considering that the recruitment peak was between March and April 2010 (Autumn), when rainfall is higher (e.g., 234 and $150 \mathrm{~mm}$, respectively). Probably, the relief of the study area aided the recruitment of $P$. pandaliformis in Rio Salsa during the rainy months. Rio Salsa exceeds its capacity during high rainfall periods and floods the margins, which increases the riverbank areas (LRP Paschoal and ECG Couto pers. observ.). As the upstream migration of juveniles occurs near the banks due to the low velocity of the flow in these areas (BAUER 2013), seasonal flood probably favoured the recruitment of $P$. pandaliformis in the margins of the river.

\section{Growth and age}

Males of $P$. pandaliformis were significantly smaller than females. Generally, males of Palaemonidae shrimps usually have larger body proportions than females because they invest and spend more energy on body growth and the acquisition of robust chelipeds, considering that larger males are more likely to mate and perform better in inter/intraspecific competition (e.g., Macrobrachium spp. males) (CoRrea \& Thiel 2003, Bauer 2004). Contrarily, females spend more energy on reproduction, which significantly reduces growth rates and explains the smaller sizes in comparison with the males (Boschi 1974). However, Correa $\&$ Thiel (2003) point out that males of many caridean species do not even protect or defend females in their own territory (i.e. "pure-search" strategy males), which suggests that larger body sizes would be unnecessary and unbeneficial. The energy that would be spent on growth is better used in events that involve successful reproduction, such as sperm production. RC 
Mortari (unpub. data) found evidence for this hypothesis for $P$. pandaliformis by noting that small individuals (CL: $1.5 \mathrm{~mm}$ ) produce a large quantity of sperm (i.e. physiological maturity), although the author does not present evidence on the capability to copulate of these small males (i.e. morphological maturity).

As suggested by PAULY \& MunRo (1984), the growth performance index $\left(\Phi^{\prime}\right)$ can be used to determine sexual dimorphism in growth, considering that it is an average of parameters obtained from VBG equations. It was possible to observe that the calculated $\Phi^{\prime}$ was very similar to that of the other congeners, and that females of $P$. pandaliformis had a greater $\Phi^{\prime}$ value than males (Table 1). This growth pattern was also observed for other species of Palaemon (Guerao et al. 1994, AraKi \& Hayashi 2002, CartaXana 2003, Kim et al. 2008, Bilgin et al. 2009a,b).

Females reached larger sizes, grew faster, and had longer life spans than males, but their growth rate $(\mathrm{K})$ was lower than that of males, indicating that there was a growth-reproduction trade-off that differs between sexes in P. pandaliformis. CARTAXANA (2003) observed slow growth of reproductive females of $P$. longirostris H. Milne Edwards, 1837during the breeding season. This pattern was also observed by Guerao et al. (1994) in P. xiphias Risso, 1816. As females of $P$. pandaliformis exhibited a high reproductive activity throughout the year (see "Reproduction" results section for further details), the investment of energy to optimize the reproductive process probably inhibits growth. According to Jones \& Simons (1983) and OH et al. (2002), the growth of females can be expectedly low or reduced during the reproduction period, when they spend more energy on oocytes development and eggs production. On the other hand, RC Mortari (unpub. data) confirms an earlier physiological maturity in small males of $P$. pandaliformis (CL: $1.5 \mathrm{~mm}$ ), which indicates that they grow quickly and mature before the females. These shrimps adopted the "pure-search" mating system strategy, thus explaining the larger size of the females and the smaller size of males (CORREA \& THIEL 2003). Male shrimps with a higher growth rate can probably reach this optimal body size sooner and are capable to copulate with large females. However, due to their shorter lifespan they disappear from the population, while the females remain and continue growing.

Since Palaemon pandaliformis is an amphidromous species, larger individuals with a longer lifespan (especially females) may have migrated to other areas not included in this study. Coelho (1964) conducted a study in a coastal lake of the state of Pernambuco (northeastern Brazil) and reported the presence of a $P$. pandaliformis female with more than $14 \mathrm{~mm}$ of CL. This value is slightly higher than the maximum theoretical CL recorded for females in this study $(13.17 \mathrm{~mm})$, and may suggest that this species can live a little longer than we estimated in the present study.

Despite the differences in body size proportions observed in species of the Palaemon genus (Table 1), the lifespan calculated in this study was very similar to the lifespan of other congeners, which suggests that amplitude can be considered a rule for this genus. Cartaxana (2003) determined that the longevity of $P$. longirostris in river Mira (Portugal) is around 15 months, while Guerao et al. (1994) estimated the lifespan of P. xiphias in Alfacs Bay (Spain) as being between 14 and 17 months, and ArAKI \& HAYASHI (2002) established a lifespan for P. gravieri (Yu, 1930) in Osaka Bay (Japan) of around 12 months.

\section{Reproduction}

The number of ovigerous females and the macroscopic observation of their ovaries during the studied period (LRP Paschoal pers. observ.) revealed that reproductive activity was continuous in P. pandaliformis. Goodbody (1965) and Diaz \& Conde (1989) found that tropical species show continuous reproduction characterised by the presence of ovigerous females and recruits throughout the year, in addition to unimodality in the grouped frequency distribution of total individuals. In this study, $P$. pandaliformis also showed this pattern (see Figs. 5-6 and 9), as observed by Lima \& Oshiro (2002) in river Sahy (Rio de Janeiro, Brazil) and Mortari et al. (2009) in river Ubatumirim (São Paulo, Brazil).

Palaemon pandaliformis showed a high reproductive activity throughout the year, and ovigerous females carrying eggs with or without eye pigmentation were recorded for all the analyzed months. Two peaks were registered: the first in summer (secondary) and the second in winter (main peak). The first peak coincides with results of the studies conducted by Mossolin \& Bueno (2002), Fransozo et al. (2004), Mortari et al. (2009), Mossolin et al. (2013), and BerTini et al. (2014) in the state of São Paulo, Brazil. These authors observed a growing trend in the occurrence of ovigerous females of different Palaemonidae species during summer only (i.e. period with the heaviest rainfall and warmest months in the southern hemisphere). However, the highest frequency of ovigerous females in the population of the present study was recorded during the second peak, that is, during winter when the rainfall is low. CaRvalHo et al. (1979) and Mantelatto \& BARBosa (2005) studied a population of Macrobrachium acanthurus (Wiegmann, 1836) and M. brasiliense (Heller, 1862), respectively, and observed a similar variation. The authors attribute this peak to factors such as migration, plant composition, food availability and water quality. Here, we attributed the winter peak to the capability of macrophyte patches (especially Brachiaria sp.) of retaining a considerable amount of organic matter. The high rainfall recorded in July 2010 probably led macrophytes to retain the direct surface flow of organic matter and the ovigerous females to assimilate this matter as a food source during the peak (LRP Paschoal unpub. data).

Ovigerous females of $P$. pandaliformis, especially those with eggs in the initial stage of development, were recorded during the entire sampling period. These females may not have exhibited downstream reproductive migration in order to hatch the larvae in saline environments. This pattern or behaviour was also recorded by BerTini et al. (2014) for M. acanthurus. These authors observed ovigerous females carrying egg at all stages in 
all the study sites during the reproductive season with no records of reproductive females disappearing far from the coast, which means there was no reproductive migration towards estuaries to hatch larvae. Other evidence relies on the presence of the ovigerous females during high water or rainy months in the river inhabited by adults, which is a reverse pattern from the pattern described by BAUER (2013).

The average fecundity registered in the present study differs from the findings of studies involving $P$. pandaliformis from different locations of Brazil, although these results lie within the margin recorded for the species (Table 2). Odinetz-Collart \& RABELo (1996) and OH et al. (1999) state that fecundity of a same species may vary due to environmental factors, food availability, variability in egg size and volume, individual age and size, and physiological conditions. Comparing our fecundity data with that of literature, we observed that fecundity is slightly greater in higher latitudes (Table 2). DefEo \& Mclachlan (2005) suggest that the marked variation in fecundity patterns could be explained by high phenotypic plasticity in the behaviour, physiology and morphology of benthic species. They also point out that plasticity permits adaptability to certain habitats. JonEs \& SIMONS (1983), however, point out that variability in fecundity can be explained by the synergy of two factors: (a) slow growth and low metabolism, resulting in more energy for egg production; and (b) increased number of broods produced by females at high latitudes.

Females of $P$. pandaliformis tend to invest more energy on growth of the brood pouch than on other parts of the body (Paschoal et al. 2013b). The abdomen and their segments suffer morphological alterations that facilitate protection during deposition, incubation and spawning (BAUER 2004). Larger brood pouches would increase the fecundity and protection of embryos during egg deposition and incubation, and consequently optimize the reproductive process (NAZARI et al. 2003, BAUER 2004). BAUER (2004) states that in females of Caridea, the main determining factor of the number of eggs laid is body size. Other factors such as parasitism, incomplete fertilization and/or diseases can also influence fecundity (COREy \& REID 1991, ANGER \& Moreira 1998, Rocha \& Bueno 2000), although to a lesser proportion when compared with the size of the female (BAUER 2004).

Palaemon spp. shows considerable differences in size and fecundity. Thus, the use of an index or common value between the most varied species is necessary for effective comparisons. Reproductive output (RO) has been applied successfully and is defined as a fraction of total energy invested in reproduction (Clarke 1987). Clarke (1987) and Lardies \& Wehrtmann (1997) studied total mass values of eggs in Caridea and found that RO in Pandalidae Haworth, 1825 varies from 17 to 24\%, in Cangronidae Haworth, 1825 from 12 to 14\%, and in Alpheidae from 9 to $17 \%$, and did not determine values for Palaemonidae. Nevertheless, $P$. pandaliformis showed a greater RO when compared with marine Palaemonids (Table 1). This is congruent with the results of ANGER \& MOREIRA (1998), who recorded a lower RO value for the marine Palaemon northropi (Rankin, 1898) in comparison with freshwater species, which suggests that this tendency can be considered a reproductive ecological rule in Palaemonidae.

Eggs in the final stages in both axes were larger than the eggs in the initial stages (for further review, see ANGER \& MOREIRA 1998). Bilgin \& SAMSUN (2006: see table 7, for review) and JANAS \& MAŃKUCKA (2010: see table 3, for review) compared increases in the change of egg diameter of marine Palaemonids and found the same pattern recorded in this study. ANDERSON (1982) states that an increase of the long axis is caused by growth of embryonic structures in the cephalic-caudal axis. NAZARI et al. (2003) suggest that during the final stage of incubation, the growth of egg axes is an important characteristic in embryogenesis since it enables greater mobility to the embryos and larvae hatching.

This study revealed that egg volume evidently increased during embryonic development. This finding was also observed by Mossolin \& BuENo (2002) for Macrobrachium olfersii (Wiegmann, 1836), and by NAZARI et al. (2003) for M. olfersi and $M$. potiuna (Müller, 1880). Among other parameters, this finding is associated with cell mobility, water absorption by cells, structural organization and embryo growth (KobaYASHI \& MATSUMUra 1995). Average egg volume of $P$. pandaliformis varied from $0.129 \pm 0.038$ $\mathrm{mm}^{3}$ in stage I and $0.203 \pm 0.058 \mathrm{~mm}^{3}$ in stage III. MorTARI et al. (2009) recorded a slightly lower value for egg volume in this species $\left(0.100 \mathrm{~mm}^{3}\right.$-Stage I) in the coast of São Paulo, Brazil. The obtained value for the population in Rio Salsa is within the size range recorded for other freshwater/estuarine Palaemonidae, such as Leander tenuicornis (Say, 1818) $\left(0.163 \mathrm{~mm}^{3}\right), P$. northropi $\left(0.200 \mathrm{~mm}^{3}\right)$, Palaemon mundusnovus De Grave \& Ashelby, 2013 $\left(0.294 \mathrm{~mm}^{3}\right)$ and Palaemon pugio (Holthuis, 1949) $\left(0.320 \mathrm{~mm}^{3}\right)$ (Corey \& ReId 1991). However, this value is higher than the values recorded for other species of Palaemon that are restricted to marine environments, such as Palaemon adspersus Rathke, 1837 (0.084-0.109 $\left.\mathrm{mm}^{3}\right)$ and Palaemon elegans Rathke, 1837 (0.039-0.053 $\mathrm{mm}^{3}$ ) (Bilgin \& SAMsun 2006).

The comparison of reproductive aspects of the population presented in this study with that of other marine Palaemonids is consistent with the observations of JALIHAL et al. (1993) and Mashío \& Numachi (2000). These studies concluded that species from inland waters have larger eggs and lower fecundity (and probably a higher RO) than marine species. Therefore, the hypothesis that Palaemonidae are undergoing a process of adaptation and colonization of freshwater environments ("freshwaterization"), as proposed by Odinetz-Collart \& Rabelo (1996) and Ashelby et al. (2012), and registered by Pantaleão et al. (2014), is supported when we compare the reproductive characteristics of marine species with those of $P$. pandaliformis.

\section{ACKNOWLEDGEMENTS}

LRPP thanks the Coordenadoria de Aperfeiçoamento de Pessoal de Nível Superior for his Master and PhD scholarships. FJG thanks FAPESB for post-doctoral scholarships (Process 
numbers FAPESB BOL1885/2009 and BOL2344/2011). We are sincerely thankful to Sérgio J Luca, who gave the opportunity to allow this work to be supported by the project: "Composição e abundância dos camarões carídeos no estuário do Rio Salsa, Canavieiras, Bahia, Brasil" (Conselho Nacional de Desenvolvimento Científico e Tecnológico process 180342/20096) and for providing the logistical support without which it would not be possible to successfully perform this study. We thank José S Rosa Filho, Alexandre O Almeida and Daniel C Cavallari by suggestions that greatly improved the paper.

\section{LITERATURE CITED}

Almeida AO, Coelho PA, Santos JTA, Ferraz NR (2006) Crustáceos decápodos estuarinos de Ilhéus, Bahia, Brasil. Biota Neotropica 6. doi: 10.1590/\$1676-06032006000200024

Anderson DT (1982) Embryology, p. 1-44. In: Abele LG (Ed.) The Biology of Crustacea. Embryology, Morphology and Genetics. New York, Academic Press, 432p.

Anger K, Moreira GS (1998) Morphometric and reproductive traits of tropical caridean shrimps. Journal of Crustacean Biology 18: 823-838. doi: 10.2307/1549156

AraKi A, HaYASHI KI (2002) Population ecology of Palaemon gravieri (Yu, 1830) (Decapoda, Caridea, Palaemonidae) in Osaka Bay, Japan. Journal of National Fisheries University 50: 75-81.

Ashelby CW, Page TJ, De grave S, Hughes JM, Johnson M (2012) Regional scale speciation reveals multiple invasions of freshwater in Palaemoninae (Decapoda). Zoologica Scripta 41: 293-306. doi: 10.1111/j.1463-6409.2012.00535.x

Baeza JA, Furlan M, Almeida AC, Barros-alves SP, Alves DF, Fransozo V (2013) Population dynamics and reproductive traits of the ornamental crab Porcellana sayana: implications for fishery management and aquaculture. Sexuality and Early Development in Aquatic Organisms 1: 1-12. doi: 10.3354/ sedao00002

BAUER RT (2004) Remarkable shrimps. Adaptations and Natural History of the Carideans. Norman, University of Oklahoma Press, 282p.

BAUER RT (2013) Amphidromy in shrimps: a life cycle between rivers and the sea. Latin American Journal of Aquatic Research 41: 633-650. doi: 10.3856/vol41-issue4-fulltext-2

Bauer RT, Delahoussaye J (2008) Life history migrations of the amphidromous river shrimp Macrobrachium ohione from a continental large river system. Journal of Crustacean Biology 28: 622-632. doi: 10.1651/08-2977.1

Bertini G, Baeza JA, Perez E (2014) A test of large-scale reproductive migration in females of the amphidromous shrimp Macrobrachium acanthurus (Caridea: Palaemonidae) from south-eastern Brazil. Marine and Freshwater Research 65: 81-93. doi: 10.1071/MF13028

Bilgin S, Ozen O, SAmsun O (2009a) Sexual seasonal growth variation and reproduction biology of the rock pool prawn, Palaemon elegans (Decapoda: Palaemonidae) in the south- ern Black Sea. Scientia Marina 73: 239-247. doi: 10.3989/ scimar.2009.73n2239

Bilgin S, SAMsun O (2006) Fecundity and egg size of three shrimp species, Crangon crangon, Palaemon adspersus, and Palaemon elegans (Crustacea: Decapoda: Caridea), off Sinop Peninsula (Turkey) in the Black Sea. Turkish Journal of Zoology 30: 413-421.

Bilgin S, SAmsun O, Ozen O (2009b) Seasonal growth and reproduction biology of the Baltic prawn, Palaemon adspersus (Decapoda: Palaemonidae), in the southern Black Sea. Journal of the Marine Biological Association of the United Kingdom 89: 509-519. doi: 10.1017/S0025315408003056

Bond-Buckup G, Buckup L (1999) Caridea (pitus, camarões de água doce e marinhos), p. 300-318. In: BucKup L, BOND-BucKup G (Eds.) Os crustáceos do Rio Grande do Sul. Porto Alegre, Editora UFRGS, 503p.

Boschi EE (1974) Biologia de los crustaceos cultivables en America Latina, p. 18-22. In: Simposio sobre Acuicultura en América Latina. Montevideo, Food and Agriculture Organization of the United States, FAO.

Cartaxana A (2003) Growth of the Prawn Palaemon longirostris (Decapoda, Palaemonidae) in Mira River and Estuary, SW Portugal. Journal of Crustacean Biology 23: 251-257. doi: 10.1163/20021975-99990334

Carvalho HA, Gomes MGS, Gondim AQ, Pereira MCG (1979) Sobre a Biologia do Pitu - Macrobrachium acanthurus (Wiegmann, 1836) em populações naturais da Ilha de Itaparica. Universitas 24: 25-45.

Clarke A (1987) Temperature, latitude and reproductive effort. Marine Ecology Progress Series 38: 89-99. doi: 10.3354/ Meps038089

Coelho PA (1964) Algumas observações sôbre a biologia e a ecologia dos camarões Palaemon northropi e $P$. pandaliformis no estado de Pernambuco (Decapoda - Palaemonidae). Trabalhos Oceanográficos da Universidade Federal de Pernambuco 5/6: 69-72

Corey S, ReID DM (1991) Comparative fecundity of decapod crustaceans, I. The fecundity of thirty-three species of nine families of caridean shrimp. Crustaceana 60: 271-294. doi: 10.1163/156854091X00056

Correa C, Thiel M (2003) Mating systems in caridean shrimp (Decapoda: Caridea) and their evolutionary consequences for sexual dimorphism and reproductive biology. Revista Chilena de Historia Natural 76: 187-203. doi: 10.4067/ S0716-078X2003000200006

De Grave S, Ashelby CW (2013) A re-appraisal of the systematic status of selected genera in Palaemoninae (Crustacea: Decapoda: Palaemonidae). Zootaxa 3734: 331-344. doi: 10.11646/ zootaxa.3734.3.3

De Grave S, Cai Y, AnKer A (2008) Global diversity of shrimps (Crustacea: Decapoda: Caridea) in freshwater. Hydrobiologia 595: 287-293. doi: 10.1007/s10750-007-9024-2

De Grave S, Fransen CHJM (2011) Carideorum Catalogus: the recent species of the Dendrobranchiate, Stenopodidean, 
Procarididean and Caridean shrimps (Crustacea: Decapoda). Zoologische Mededelingen 85: 195-589.

Defeo O, Mclachlan A (2005) Patterns, processes and regulatory mechanisms in sandy beach macrofauna: a multi-scale analysis. Marine Ecology Progress Series 295: 1-20. doi: 10.3354/meps295001

Diaz H, Conde JE (1989) Population dynamics and life history of the mangrove crab Aratus pisonii (Brachyura, Grapsidae) in a marine environment. Bulletin of Marine Science 45: 148-163.

D'INCAO F, FonsECA DB (1999) The performance of the von Bertalanffy growth curve in penaeid shrimps: a critical approach, p. 733-737. In: Von Klei JC, Schram FR (Eds.) The biodiversity crisis and Crustacea: Proceedings of the Fourth International Crustacean Congress. Rotterdam, A.A. Balkema.

FERREIrA RS, VieIra RRR, D'INCAO F (2010) The marine and estuarine shrimps of the Palaemoninae (Crustacea: Decapoda: Caridea) from Brazil. Zootaxa 2606: 1-24.

FISHER RA (1930) The genetical theory of natural selection. New York, Claredon Press, 308p.

FonseCA DB, D'INCAO F (2003) Growth and reproductive parameters of Kalliapseudes schubartii in the estuarine region of the Lagoa dos Patos (southern Brazil). Journal of the Marine Biological Association of the UK 83: 931-935. doi: 10.1017/ S0025315403008087h

Foster C, Amado EM, Souza MM, Freire CA (2009) Do osmoregulators have lower capacity of muscle water regulation than osmoconformers? A study on decapod crustaceans. Journal of Experimental Zoology 313: 80-94. doi: 10.1002/jez.575

Fransozo A, Rodrigues FD, Freire FAM, Costa RC (2004) Reproductive biology of the freshwater prawn Macrobrachium iheringi (Ortmann, 1897) (Decapoda: Caridea: Palaemonidae) in the Botucatu region, São Paulo, Brazil. Nauplius 12: 119-126.

Gavio MA, Orensanz JM, Armstrong D (2006) Evaluation of alternative life history hypotheses for the sand shrimp Crangon franciscorum (Decapoda: Caridea). Journal of Crustacean Biology 26: 295-307. doi: 10.1651/C-2619.1

Goodbody H (1965) Continuous breeding in populations of two tropical crustaceans, Mysidium columbiae (Zimmer) and Emerita portoricensis Schmidt. Ecology 46: 195-197. doi: $10.2307 / 1935274$

Guerao G, Pérez-baquera J, Ribera C (1994) Growth and reproductive biology of Palaemon xiphias Risso, 1816 (Decapoda,Caridea, Palaemonidae). Journal of Crustacean Biology 14: 280-288. doi: $10.2307 / 1548908$

Jalihal DR, SAnkolli KN, Shenoy S (1993) Evolution of larval developmental patterns and the process of freshwaterization in the prawn genus Macrobrachium Bate, 1868 (Decapoda, Palaemonidae). Crustaceana 65: 365-376. doi: $10.1163 / 156854093 X 00793$

JANAS U, MAŃKUCKA A (2010) Body size and reproductive traits of Palaemon elegans Rathke, 1837 (Crustacea, Decapoda), a recent colonizer of the Baltic Sea. International Journal of
Oceanography and Hydrobiology 39: 3-24. doi: 10.2478/ v10009-010-0016-6

Jones MB, Simons MJ (1983) Latitudinal variation in reproductive characteristics of a mud crab, Helice crassa (Grapsidae). Bulletin of Marine Science 33: 656-670.

Кім JC, Он CW, PAIK SG (2008) Reproduction and growth of the freshwater prawn, Palaemon paucidens (Decapoda: Palaemonidae) in a lake of Korea. Journal of Environmental Biology 29: 163-168.

Kobayashi S, Matsumura S (1995) Egg development and variation of egg size in the japanese mitten crab Eriocheir japonicus (De Haan). Benthos Research 48: 29-39. doi: 10.1163/193724012X649796

LARDIES MA, WeHRTMANN IS (1997) Egg production in Betaeus emarginatus (H. Milne Edwards, 1837) (Decapoda: Alpheidae): fecundity, reproductive output and chemical composition of eggs. Ophelia 46: 165-174. doi: 10.1080/00785326.1997.10432582

Lima GV, Oshiro LMY (2002) Aspectos reprodutivos de Palaemon pandaliformis (Stimpson) (Crustacea, Decapoda, Palaemonidae) no Rio Sahy, Mangaratiba, Rio de Janeiro, Brasil. Revista Brasileira de Zoologia 19: 855-860. doi: 10.1590/S010181752002000300023.

Mantelatto FLM, Barbosa LR (2005) Population structure and relative growth of freshwater prawn Macrobrachium brasiliense (Decapoda, Palaemonidae) from São Paulo State, Brazil. Acta Limnologica Brasiliensia 17: 245-255.

Mashiкo K, Numachi K (2000) Derivation of populations with different-sized eggs in the palaemonid prawn Macrobrachium nipponense. Journal of Crustacean Biology 20: 118-127. doi: 10.1163/20021975-99990021

Melo GAS (2003) Famílias Atyidae, Palaemonidae, Sergestidae, p. 289-415. In: Melo GAS (Ed.). Manual de Identificação dos Crustacea Decapoda de água doce do Brasil. São Paulo, Editora Loyola.

Mortari RC, Pralon BGN, Negreiros-fransozo ML (2009) Reproductive biology of Palaemon pandaliformis (Stimpson, 1871) (Crustacea, Decapoda, Caridea) from two estuaries in southeastern Brazil. Invertebrate Reproduction and Development 53: 223-232. doi: 10.1080/07924259.2009.9652308

Mossolin EC, Bueno SLS (2002) Reproductive biology of Macrobrachium olfersii (Decapoda, Palaemonidae) in São Sebastião, Brazil. Journal of Crustacean Biology 22: 367-376. doi: 10.1651/0278-0372(2002)022[0367:RBOMOD]2.0.CO;2

Mossolin EC, Peirò DF, Rossingnoli MO, Rajab LP, Mantelatto FLM (2013) Aspectos populacionais e reprodutivos do camarão de água doce Macrobrachium jelskii (Miers, 1877) do Estado de São Paulo, Brasil. Acta Scientiarum. Biological Sciences 35: 429-436. doi: 10.4025/actascibiolsci.v35i3.15815

Nazari EM, Simões costa MS, Muller YMr, Ammar D, Dias M (2003) Comparisons of fecundity, egg size and egg mass volume of the freshwater prawns Macrobrachium potiuna and Macrobrachium olfersii (Decapoda, Palaemonidae). Journal of Crustacean Biology 23: 862-868. doi: 10.1651/C-2387 
Odinetz-Collart O, Rabelo H (1996) Variation in egg size of the freshwater prawn Macrobrachium amazonicum (Decapoda, Palaemonidae). Journal of Crustacean Biology 16: 684-688. doi: $10.2307 / 1549189$

Oh CW, Hartnoll RG, Nash RDM (1999) Population dynamic of the common shrimp, Crangon crangon (L.), in Port Erin Bay, Isle of Man, Irish Sea. Journal of Marine Sciences 56: 718-733. doi: 10.1006/jmsc.1999.0501

OH CW, Suh HL, Park KY, Ma C, Lim H (2002) Growth and reproductive biology of the Freshwater shrimp Exopalaemon Modestus (Decapoda: Palaemonidae) in a lake of Korea. Journal of Crustacean Biology 22: 357-366. doi: 10.1651/0278-0372(2002)022[0357:GARBOT]2.0.CO;2

Pantaleão JAF, Hirose GL, Costa RC (2014) Ocurrence of male morphotypes of Macrobrachium amazonicum (Caridea, Palaemonidae) in a population with an entirely freshwater life cycle. Brazilian Journal of Biology 74: 223-232. doi: 10.1590/1519-6984.03713

Paschoal LRP Souza RM, Guimarães FJ, Couto ECG (2013a) Phytophilous caridean shrimps (Atyidae and Palaemonidae) in Salsa river (Canavieiras, Bahia, Brazil). Nauplius 21: 123-126. doi: 0.1590/S0104-64972013000100011

Paschoal LRP, Guimarães FJ, Couto ECG (2013b) Relative growth and sexual maturity of the freshwater shrimp Palaemon pandaliformis (Crustacea: Palaemonidae) in northeast of Brazil (Canavieiras, Bahia). Iheringia, Série Zoologia, 103: 31-36. doi: 10.1590/S0073-47212013000100004

Pauly D, Munro JL (1984) Once more on the comparison of growth in fish and invertebrates. Fishbyte 2: 21.

Rocha SS, Bueno SS (2000) Probopyrus floridensis Richardson, 1904 (Isopoda, Bopyridae) paraziting the freshwater prawn
Macrobrachium potiuna (Müller, 1880), from São Paulo, Brazil. Nauplius 8: 133-140.

Rosa LC, Passos AC, CorrêA MFM (2015) Aspectos populacionais e reprodutivos de Palaemon pandaliformis (Crustacea: Palaemonidae) em uma marisma subtropical no sul do Brasil. Boletim do Instituto de Pesca 41: 849-857.

TeIXeIRA RL (1997) Distribution and feeding habits of the young common snook, Centropomus undecimalis (Pisces: Centropomidae), in the shallow waters of a tropical Brazilian estuary. Boletim do Museu de Biologia Mello Leitão 6: 35-46.

WenNer AM (1972) Sex-ratio as a function of size in marine Crustacea. The American Naturalist 106: 321-350. doi: $10.1086 / 282774$

Wilson MF, Pianka ER (1963) Sexual selection, sex ratio and mating system. The American Naturalist 97: 405-407. doi: $10.1086 / 282292$

Submitted: 1 April 2016

Received in revised form: 24 July 2016

Accepted: 8 August 2016

Editorial responsibility: Adriano S. Melo

Author contributions. LRPP, FJG and ECGC conceived and designed the study; LRPP and FJG conducted the study and analyzed the data; LRPP, FJG and ECGC wrote the paper. Competing Interests: The authors have declared that no competing interests exist. 